Original Research Paper

\title{
Trace of Salinity of Sodium Chloride with Outcome on Enhancement Features of Herbage
}

\author{
${ }^{1}$ Sona Pazdar, ${ }^{2}$ Saeid Eslamian, ${ }^{3}$ Kaveh Ostad-Ali-Askari, ${ }^{3}$ Hossein Gholami, ${ }^{4}$ Vijay P. Singh, \\ ${ }^{5}$ Mohsen Ghane, ${ }^{6}$ Shahide Dehghan and ${ }^{2}$ Majedeh Haeri-Hamedani \\ ${ }^{1}$ Civil Engineering Department, Aghigh University, Shahinshahr, Iran \\ ${ }^{2}$ Department of Water Engineering, College of Agriculture, Isfahan University of Technology, Isfahan, Iran \\ $3^{3 *}$ Department of Civil Engineering, Isfahan (Khorasgan) Branch, Islamic Azad University, Isfahan, Iran \\ ${ }^{4}$ Department of Biological and Agricultural Engineering \& Zachry Department of Civil Engineering, \\ Texas A and M University, 321 Scoates Hall, 2117 TAMU, College Station, Texas 77843-2117, U.S.A \\ ${ }^{5}$ Department of Civil Engineering, South Tehran Branch, Islamic Azad University, Tehran, Iran \\ ${ }^{6}$ Department of Geography, Najafabad Branch, Islamic Azad University, Najafabad, Iran
}

Article history

Received: 21-10-2018

Revised: $13-03-2019$

Accepted: 26-06-2019

Corresponding Author:

Kaveh Ostad-Ali-Askari

Department of Civil Engineering,

Isfahan (Khorasgan) Branch,

Islamic Azad University, Isfahan, Iran

Email: kaveh.oaa2000@gmail.com

koa.askari@khuisf.ac.ir

\begin{abstract}
Salinity has a variety of salts, one of which is salinity of sodium chloride. Different plants react differently to salinity and their performance will vary according to their resistance, which after all the treatments, chlorophyll was measured. Depend on the outcomes of salinity consequences on native herbage; herbage features such as relative chlorophyll and chlorophyll fluorescence were decreased. Also, salinity reduced the amount of potassium in the leaf and root, as well as increased sodium levels in the leaves and roots. This trait is the highest in control treatment and the lowest in treatment with $125 \mathrm{mg} / \mathrm{L}$ sodium chloride. Root length index was decreased to $1.25 \mathrm{mg} / \mathrm{L}$ sodium chloride in comparison to control treatment. This attribute is the level of $25 \mathrm{mM}$ was not significant compared to the control. At the highest level of salinity $(125 \mathrm{mM} / \mathrm{L}$ sodium chloride), the sodium content of the limb increased by about 3.5 times as much as the control. The number of leaves and the relative chlorophyll content of the control treatment were $48.65 \%$ and $52.31 \%$ higher than the salinity treatments. According to the article the potassium content of stems and roots in the control treatment is higher than that of $125 \mathrm{mg}, 55.7 \%$ and $66.53 \%$. And the sodium content of stem and root of the control treatment was reduced to 69.57 and 14.17 , respectively, to $125 \mathrm{mg}$. In the control treatment, inarticle, potassium content is higher than sodium, but in the 125 mg salinity treatment, the sodium content is higher than that of potassium. And the amount of $125 \mathrm{mg}$ salinity treatment in Sodium was $49.26 \%$ higher than the sodium root. And the amount of $125 \mathrm{mg}$ salinity treatment in potassium is $68.22 \%$ higher than potassium root. Chlorophyll fluorescence inarticle. In control, treatment is $17 \%$ higher than salinity treatment.
\end{abstract}

Keywords: Sodium Chloride, Chlorophyll, Potassium, Salinity

\section{Introduction}

About half of the world's water is affected by salinity. The best method for obtaining proper function in saline soils is using saline resistant plants (Hayley et al., 2013). A degree of the sensitivity of vegetables is very different from soil salinity (Juchem et al., 2012). The most sensitive vegetables are salinity of celery and radish soil and the most resistant are spinach and beet. Salinity has several types, one of which is sodium chloride salinity. In this Article, features such as relative chlorophyll, chlorophyll fluorescence, sodium levels and potassium of root and stem were measured (Greenwood et al., 1980).

\section{A Review of Prior Studies}

Salinity increases the concentration of soluble salts and water-soluble mineral soils that results in salt accumulation in the root zone, to the extent that prevents optimal growth of the plant (Chris, 1996). The first accumulated ions are sodium and chlorine, but cations 
such as calcium and magnesium and anions such as sulfate and bicarbonate also cause salinity (Hardegree et al., 2000). The other side of these effects is the high amount of sodium or calcium in the soil that can interfere with the absorption of other elements or the metabolism of the plant. Salinity reduces the percentage and rate of germination in both groups of pretreated seeds (Durrant et al., 1993; Khorasani and Armstrong, 1990).

Mr. Ghorbani was done on wheat seeds. The effects of salinity on all germination components including the time to germination, time to $90 \%$ germination, uniformity and emergence were very significant and salinity increased the percentage, speed and uniformity of germination in wheat (Kamkar et al., 2004). Sodium chloride increases osmotic potential due to the inhibitory effect on water absorption by seed (Francisco and Grattan, 2009). Germination percentage and root and shoot length of wheat decreased with increasing salinity stress. Sodium chloride has a toxic effect on the embryo and endosperm cell membrane (Farooq et al., 2007). Other causes of growth and plant depletion due to salinity, increased energy consumption in the plant to extricate the invading sodium ions that are present in large amounts (Foti et al., 2008).

\section{Materials and Methods}

This Article was performed from October 2013 to spring 2014 in Isfahan University of Technology Research Center at Isfahan University of Technology to consider the trace of brininess (sodium chloride) on formation signs of Isfahan native herbages.

In this research, seeds of native herbage were provided and fumigated with hypochlorite $2 \%$. Also, vases with a height of $30 \mathrm{~cm}$ and a diameter of $25 \mathrm{~cm}$ were fumigated with $25 \%$ Vichy (Gulzar and Khan, 2001). The combination of occupied and sand was blended in a 1: 1 proportion. In order to do this probe, five areas of salinity of $25,50,75,100$ and 125 millimoles were provided and practiced. All salinity dilutions, in addition to sodium chloride salt, need 1 to 1000 times the fluorine (Haigh et al., 1985). The 25milliliter saline solution that was provided was 60 liters and 87 grams of sodium chloride and 60 grams of fluorine were required to make this dilution.

Firstly, about two-thirds of the vases were cumulated with pre-provided blending medium (cocopeat and sand) (Harris et al., 2001). Then in each vase, four grains were planted with spacing. For the time of planting, the seeds should be intact and then sprinkled slightly onto the seeds to cover the surface (the quantity of soil on the seed area is roughly the greatest seed diameter). Irrigation was carried out after planting pots (Foti et al., 2002). The pots were located in 6 rows of 5 rows and a salinity treatment was applied in each row. To keep away from changing and changing the vases, labeling is needed (Ghavami and Rezai, 2000).
First, irrigation was carried out at short interims. The endemic herbage of Isfahan has a fast pullulation so that in this article, about $70 \%$ of seeds peeped three days after planting. Therefore, low drought and irrigation can cause their buds to dry (Fret et al., 1991).

In the first stage, all of the vases were irrigated with control dilution (water and fluorine). This irrigation continued until two original leaves, which continued for 14 days (Hus and Sung, 1997). In the second step, we irrigated the control row with the control solution and all other rows $(25,50,75,100$ and 125) with $25 \mathrm{mg}$ solution to barricade the herbages from experiment sudden stress. In the third step of the first row with the control dilution, the second row was irrigated with 25 $\mathrm{mM}$ dilution and the rest of the rows were irrigated with $50 \mathrm{mM}$ dilution (Heydecker, 1977).

\section{Results and Discussion}

The topic of salt acceptance has received a tremendous amount of consideration during the past two decades. The perception of developing salt-tolerant vegetations, even to the degree that they can be grown with seawater, captures the imagination of both the technical and the public sector (Grieve et al., 2004). In leaves of kind of species, the $\mathrm{Ca}$ and $\mathrm{Mg}$ concentration reduced with enhancing salinity level. harmful alterations in the mineral composition of forage species in response to salinity can be kept down by selecting proper species. In many cases, the value of the water is reduced exclusively because of its higher salt absorption (Kaur et al., 2002). Even though quantifiable evidence on crop salt tolerance occurs for kind of crop species, there are many herbages which lack definitive data (Robinson et al., 2004) herbages crops are well-defined as herbaceous types grown for human feeding in which the eatable portions consist of leaves, roots, hypocotyls, stems, petioles and flower buds (David et al., 2007). The salt acceptance of herbal types is significant because the cash value of herbages is usually high. Some universal data is offered on how salinity affects herbage growth and progress and how diverse measurements of salinity in solution cultures, sand cultures and field studies can be reconciled to a public origin. The salt acceptance of herbages has been condensed and reported in a uniform plan based on the best existing information (Elisa et al., 2019; Michael 1997). Differences and contradictions exist in some of the data due to differences in cultivars, environments and experimental conditions. For a great number of kinds little or no valuable data occurs and there is a clear need for research. In universal, herbal growth and vital oil content and yield decreased with an increase in 
water salinity in all the types (Grattan et al., 2004). There is a wide range of salt acceptance in vascular herbals. There is presently a necessity to progress new direction and cohesive impetus in the area of salttolerant crops growth. Accumulation of salinity in the root zone can be harmful to sustained crop production (Harris, 1996). Irrigation, even with temperately saline water, impulses collected salts deeper into the root zone, allowing roots to increase in regions of relatively low salinity (Suyama et al., 2007). The salinization and water shortage of soil are extensive environmental difficulties in limiting plant survival, growth and productivity (Heidari-Sharifabad et al., 2006). However, some herbages could adopt some strategies to resist salinity and drought stresses. We conclude the results of salinity generate by $\mathrm{Na}$ salts when water is not restricting, is related not only to plant species but also to their stages of growth (Guzman and Olave, 2004). There is a range of herbages that are proficient of growing under situations of saline soil and water. At high salt concentrations, production levels drop and the plant options diminution meaningfully (Hussian et al., 2006). Significantly, however, the mineral composition of the herbages may be expressively changed by the concentration and kind of salts in the soil and water (Jumsoon et al., 1996).

This trait was highest in control treatment and showed the lowest amount at $25 \mathrm{mg} / \mathrm{L}$ sodium chloride. The comparisons showed that salinity levels of $25 \mathrm{~mol} / \mathrm{L}$ sodium chloride significantly reduced leaf relative chlorophyll content compared to control treatment. Salinity levels of 25 with 50, 75 and 75 with 100 levels do not differ significantly (Table 3) (Michell, 1995).

Reducing the number of leaves was under the influence of salinity treatment, with the trait at the level of $100 \mathrm{mM} / \mathrm{L}$, the highest decrease. The number of leaves of 25 and 50 and $75 \mathrm{mM} / \mathrm{L}$ salt sodium chloride did not differ significantly (Table 3) (Kara, 1998).

Increased ion leakage has been affected by salinity treatment, so that this trait has the highest level and has the lowest level in salinity treatment with $125 \mathrm{mg} / \mathrm{l}$ sodium chloride (Table 4).

As the results indicated, the sodium content of the root increased proportional to the salt concentration, so that in the control treatment, 25 and $50 \mathrm{mM} / \mathrm{L}$ sodium chloride, the lowest amount of sodium accumulation in the root was observed and at the level of $125 \mathrm{mg} / \mathrm{L}$, the highest sodium chloride Sodium of the root was observed (Table 4).

Thus, this trait has the lowest amount in control treatment and has the highest rate in $125 \mathrm{MM}$ sodium chloride treatment. The difference between other salinity concentrations was also significant (Table 4).

Also, the results of this experiment indicated that in the cucumber of the native variety of Isfahan, with an increasing salt concentration in the environment, the amount of sodium in the leaf and root increased (Table 5). By comparing the results, it was found that the sodium ion concentration in the root was generally higher than the earial Limb. With increasing salinity levels, more sodium was accumulated in the root of the plant, while sodium was found to be less in its leaves (Tables 1 and 4).

Table 1: Analysis $\mathrm{NaCl}$ of variance of salinity effects on ion leakage and the amount of sodium and potassium elements in root and stems in native cucumber in Isfahan

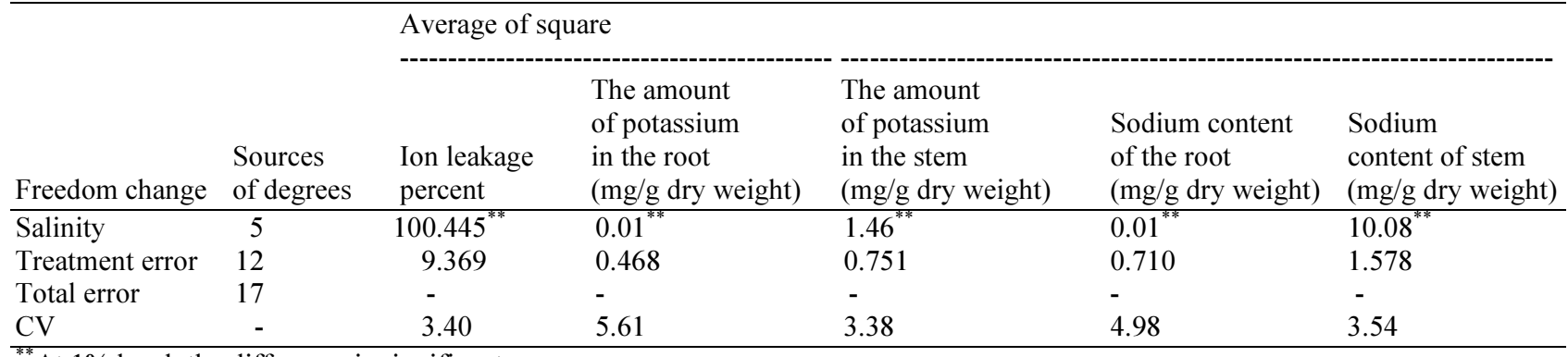

${ }^{* *}$ At $1 \%$ level, the difference is significant

Table 2: Analysis of variance $\mathrm{NaCl}$ of effect on chlorophyll fluorescence indices measured in third leaf of high in Isfahan native cucumber

\begin{tabular}{|c|c|c|c|c|c|}
\hline \multirow[b]{2}{*}{ Freedom change } & \multirow[b]{2}{*}{ Sources of degrees } & \multicolumn{4}{|c|}{ average of squares } \\
\hline & & Fo & $\mathrm{FV}_{\mathrm{V}}$ & $\mathrm{Fm}$ & $\mathrm{Fv} / \mathrm{Fm}$ \\
\hline Salinity & 5 & $8221.79^{* *}$ & $13587.10^{* *}$ & $3476.96^{* *}$ & $0.0052^{* *}$ \\
\hline treatment error & 24 & 19.46 & 134.90 & 12.05 & 0.0001 \\
\hline total error & 29 & - & - & - & - \\
\hline $\mathrm{CV}$ & - & 1.96 & 1.53 & 0.33 & 1.50 \\
\hline
\end{tabular}

${ }^{* *}$ At $1 \%$ level, the difference is significant 
Table 3: Comparison of the mean of salinity $\mathrm{NaCl}$ effects on leaf number, ion leakage and relative chlorophyll in native cucumber of Isfahan

\begin{tabular}{llll}
\hline Treatment & $\begin{array}{l}\text { Ion leakage } \\
\text { percent }\end{array}$ & $\begin{array}{l}\text { Number } \\
\text { of leaves }\end{array}$ & $\begin{array}{l}\text { Relative } \\
\text { chlorophyll }\end{array}$ \\
\hline Witness & $81.304^{\mathrm{d}}$ & $7.40^{\mathrm{a}}$ & $32.50^{\mathrm{a}}$ \\
Salinity $25 \mathrm{mM}$ & $88.945^{\mathrm{bc}}$ & $6.40^{\mathrm{b}}$ & $25.50^{\mathrm{b}}$ \\
Salinity $50 \mathrm{mM}$ & $87.467^{\mathrm{c}}$ & $6.20^{\mathrm{b}}$ & $26.50^{\mathrm{b}}$ \\
Salinity $75 \mathrm{mM}$ & $89.532^{\mathrm{bc}}$ & $6.00^{\mathrm{b}}$ & $23.50^{\mathrm{bc}}$ \\
Salinity $100 \mathrm{mM}$ & $93.794^{\mathrm{ab}}$ & $4.80^{\mathrm{c}}$ & $20.50^{\mathrm{c}}$ \\
Salinity $125 \mathrm{mM}$ & $98.349^{\mathrm{a}}$ & $3.80^{\mathrm{d}}$ & $15.50^{\mathrm{e}}$ \\
\hline
\end{tabular}

In each column, averages that have at least one common alphabet, based on the LSD test, have no significant difference at the 5\% probability level

Table 4: The effect of $\mathrm{NaCl}$ salinity on sodium and potassium elements of root and shoots of isfahan native cucumbers

\begin{tabular}{lllll}
\hline Treatment & $\begin{array}{l}\text { Potassium stem } \\
(\mathrm{mg} / \mathrm{g} \text { dry weight) }\end{array}$ & $\begin{array}{l}\text { Potassium root } \\
(\mathrm{mg} / \mathrm{g} \text { dry weight) }\end{array}$ & $\begin{array}{l}\text { Sodium Stem } \\
\text { (mg/g dry weight) }\end{array}$ & $\begin{array}{l}\text { Sodium root } \\
\text { (mg/g dry weight) }\end{array}$ \\
\hline Witness & $83.174^{\mathrm{a}}$ & $34.992^{\mathrm{a}}$ & $26.668^{\mathrm{e}}$ & $28.664^{\mathrm{d}}$ \\
Salinity $25 \mathrm{mM}$ & $53.702^{\mathrm{b}}$ & $28.956^{\mathrm{c}}$ & $63.820^{\mathrm{d}}$ & $29.680^{\mathrm{d}}$ \\
Salinity $50 \mathrm{mM}$ & $46.374^{\mathrm{c}}$ & $32.556^{\mathrm{b}}$ & $70.372^{\mathrm{c}}$ & $30.376^{\mathrm{d}}$ \\
Salinity $75 \mathrm{mM}$ & $47.798^{\mathrm{c}}$ & $23.052^{\mathrm{d}}$ & $75.220^{\mathrm{b}}$ & $33.904^{\mathrm{c}}$ \\
Salinity $100 \mathrm{mM}$ & $40.170^{\mathrm{d}}$ & $15.048^{\mathrm{e}}$ & $94.024^{\mathrm{a}}$ & $37.192^{\mathrm{b}}$ \\
Salinity $125 \mathrm{mM}$ & $36.854^{\mathrm{e}}$ & $11.712^{\mathrm{f}}$ & $96.232^{\mathrm{a}}$ & $42.832^{\mathrm{a}}$ \\
\hline
\end{tabular}

In each column, averages that have at least one common alphabet, based on the LSD test, have no significant difference at the $5 \%$ probability level

Table 5: Comparison of the mean of salinity effects $\mathrm{NaCl}$ on chlorophyll fluorescence indices measured in third leaf of high in Isfahan native cucumbers

\begin{tabular}{lllll}
\hline Treatment & Fo & Fv & Fm & Fv/Fm \\
\hline Witness & $843.80^{\mathrm{a}}$ & $1083.2^{\mathrm{a}}$ & $227.40^{\mathrm{b}}$ & $0.779^{\mathrm{a}}$ \\
Salinity $25 \mathrm{mM}$ & $798.00^{\mathrm{b}}$ & $1074.2^{\mathrm{b}}$ & $222.80^{\mathrm{b}}$ & $0.742^{\mathrm{b}}$ \\
Salinity $50 \mathrm{mM}$ & $758.20^{\mathrm{c}}$ & $1062.2^{\mathrm{c}}$ & $208.00^{\mathrm{c}}$ & $0.713^{\mathrm{c}}$ \\
Salinity $75 \mathrm{mM}$ & $741.80^{\mathrm{d}}$ & $1040.8^{\mathrm{d}}$ & $222.40^{\mathrm{b}}$ & $0.712^{\mathrm{c}}$ \\
Salinity $100 \mathrm{mM}$ & $727.20^{\mathrm{d}}$ & $1029.2^{\mathrm{e}}$ & $222.80^{\mathrm{b}}$ & $0.706^{\mathrm{c}}$ \\
Salinity $125 \mathrm{mM}$ & $699.00^{\mathrm{e}}$ & $1016.4^{\mathrm{f}}$ & $247.60^{\mathrm{a}}$ & $0.687^{\mathrm{d}}$ \\
\hline
\end{tabular}

In each column, averages that have at least one common alphabet, based on the LSD test, have no significant difference at the 5\% probability level

Reducing the number of leaves was under the influence of salinity treatment, with the trait at the level of $100 \mathrm{mM} / \mathrm{L}$, the highest decrease. The number of leaves of 25 and 50 and $75 \mathrm{mM} / \mathrm{L}$ salt sodium chloride did not differ significantly (Table 5 ).

The analysis table for variance (4-4) shows that salinity had a significant effect on ion leakage at $1 \%$ probability level. Increased ion leakage has been affected by salinity treatment, so that this trait has the highest level and has the lowest level in salinity treatment with $125 \mathrm{mg} / \mathrm{l}$ sodium chloride (Table 5).

This trait was highest in control treatment and showed the lowest amount at $25 \mathrm{mg} / \mathrm{L}$ sodium chloride. The comparisons showed that salinity levels of 25 $\mathrm{mol} / \mathrm{L}$ sodium chloride significantly reduced leaf relative chlorophyll content compared to control treatment. Salinity levels of 25 with 50,75 and 75 with 100 levels do not differ significantly (Table 5).

According to the variance analysis Table 1 , in this experiment, the effect of salinity on potassium content of the root was significant at $1 \%$ probability level. The results showed that with increasing salt concentration, potassium content of the root decreases, except for the 25 and 50 treatments, which correlate the photo mode. The highest root potassium in control treatment and the lowest amount in $125 \mathrm{mM} / \mathrm{L}$ sodium chloride treatment was observed (Table 4) (Jennette et al., 2002).

The analysis table for the variance of 2-4 showed that the effect of salinity on leaf potassium levels was significant at $1 \%$ probability level. The mean comparison table also indicates that, with increasing salinity levels, the amount of potassium in the plant's earial Limb decreased. At the highest salinity level (125 mM/L sodium chloride per liter), the amount of potassium obtained in the leaf of the plant was 25.2 times lower than the control treatment. In this experiment, the highest amount of potassium accumulation in the control group was observed in the control group. Conversely, this trait showed the lowest level at $125 \mathrm{mM} / \mathrm{L}$ sodium chloride (Table 4). 
The analysis of variance Table 4 showed that the effect of sodium chloride on the chlorophyll fluorescence index was significant at $1 \%$ probability level. The results of the data showed that the mean chlorophyll fluorescence index decreased with increasing salinity level, which indicates the effect of salinity on the efficiency of the photosystem. As the results showed, chlorophyll fluorescence index was highest in control treatment but decreased with increasing salt concentration, so that chlorophyll fluorescence index decreased at the lowest salinity level $(25 \mathrm{mM} / \mathrm{L}$ sodium chloride) compared to control and ultimately at the highest salinity level (125 mM/L sodium chloride), which was about 1.1 times lower than the control. Also, the results indicated that the chlorophyll fluorescence index showed a lower reduction in the aerial limb growth index, which was measured with increasing salt concentration (Table 5) (Herbage et al., 1974).

The chlorophyll fluorescence index is a good measure of photosynthetic activity and can be used to evaluate the damage to the photosynthetic device. In this experiment, data analysis showed that the mean chlorophyll fluorescence index decreases with increasing salinity levels, which indicates the effect of salinity on the efficiency of the photosystem (Table 3).

The analysis of variance Table 2 showed that the effect of sodium chloride on the chlorophyll fluorescence index was significant at $1 \%$ probability level. The results of the data showed that the mean chlorophyll fluorescence index decreased with increasing salinity level, which indicates the effect of salinity on the efficiency of the photosystem. As the results showed, chlorophyll fluorescence index was highest in control treatment but decreased with increasing salt concentration, so that chlorophyll fluorescence index decreased at the lowest salinity level $(25 \mathrm{mM} / \mathrm{L}$ sodium chloride) compared to control and ultimately at the highest salinity level $(125 \mathrm{mM} / \mathrm{L}$ sodium chloride), which was about 1.1 times lower than the control. Also, the results indicated that the chlorophyll fluorescence index showed a lower reduction in the aerial limb growth index, which was measured with increasing salt concentration (Table 5).

\section{Conclusion}

The concentration of sodium ion in the root is greater than that of the air. With increasing salinity, more sodium was accumulated in the root of the plant, while sodium was found to be less in the leaf. With increasing salt concentration, the highest root potassium in control treatment and the lowest amount in $125 \mathrm{mg} / \mathrm{L}$ sodium chloride treatment were observed. At the highest level of salinity $(125 \mathrm{~mm} / \mathrm{L}$ sodium chloride per liter), the amount of potassium obtained in the leaf of the plant was 25.2 times lower than the control treatment.

And according to Table 1, the potassium content of the stem is 141.161 higher than the potassium content of the root. (In dry state) and the sodium content of the stem is higher than the sodium content of the root at 458.299 (in dry condition). And the treatment error for sodium levels is higher than the potassium error rate. Treatment error has a 34\% root stroke rootstock root stock root error and Sodium stalk treatment error is $52.4 \%$ higher than stem potassium. And potassium stalk treatment error is $37.68 \%$ higher than root potassium. Sodium stalk treatment is more than $55 \%$ higher than root sodium. Figure 2 shows Formal review of salinity pressure in herbs and commensurate inherent physiological answers. It also displays Salinity stress at begins and the result of Salinity stress is Recovery/Adapation. It divides two stages Osmotic stress and Ionic stress. Then both of them follow Signal transduction (call death). Two stages ( Osmotic adjustment, Ion homeostasis) follow Recovery/ Adaption.

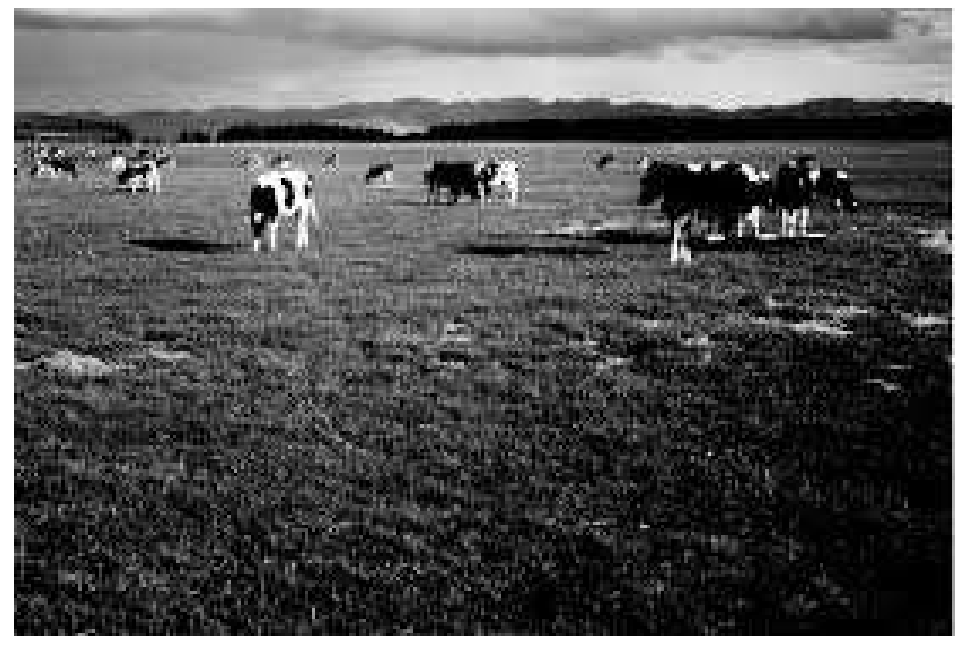

Fig. 1: Salt in farmland 
The trace of salinity of sodium chloride on herbages features of local plants in area has a minus trace in enhancing the condensation of salinity conduct, subtractive in herbage features such as relative chlorophyll, chlorophyll fluorescence and number of leaves decreases.

Figure 1 show s a fram which is measured it's effect of the salt in farmland. It considers salinity stress in herbs and conforming essential biological answers. Two stages (Osmotic stress and Ionic stres) due to the Signal transduction and two stages derives from Signal transduction (Osmotic adjustment Accumulation of ions/organic compounds and Ion homeostasis $\mathrm{Na}+$ extrusion/Na+ copmpartmentation/ $\mathrm{Na}+$ reabsorption) then They due to the recovery/adpation (Partly adapted from Horie et al., 2012).

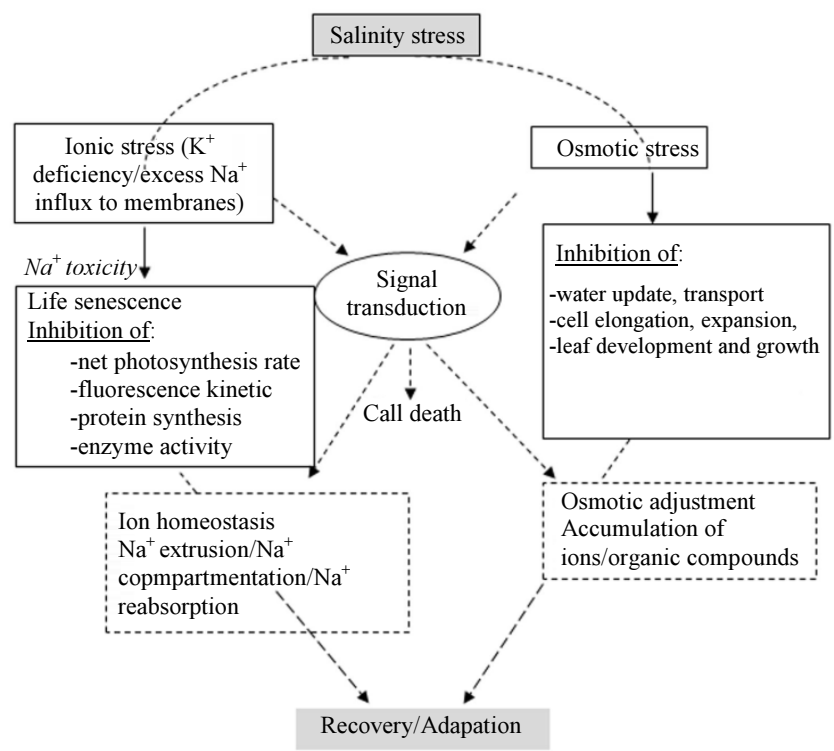

Fig. 2: Schematic summary of salinity stress in plants and corresponding intrinsic physiological responses (Partly adapted from Horie et al., 2012)

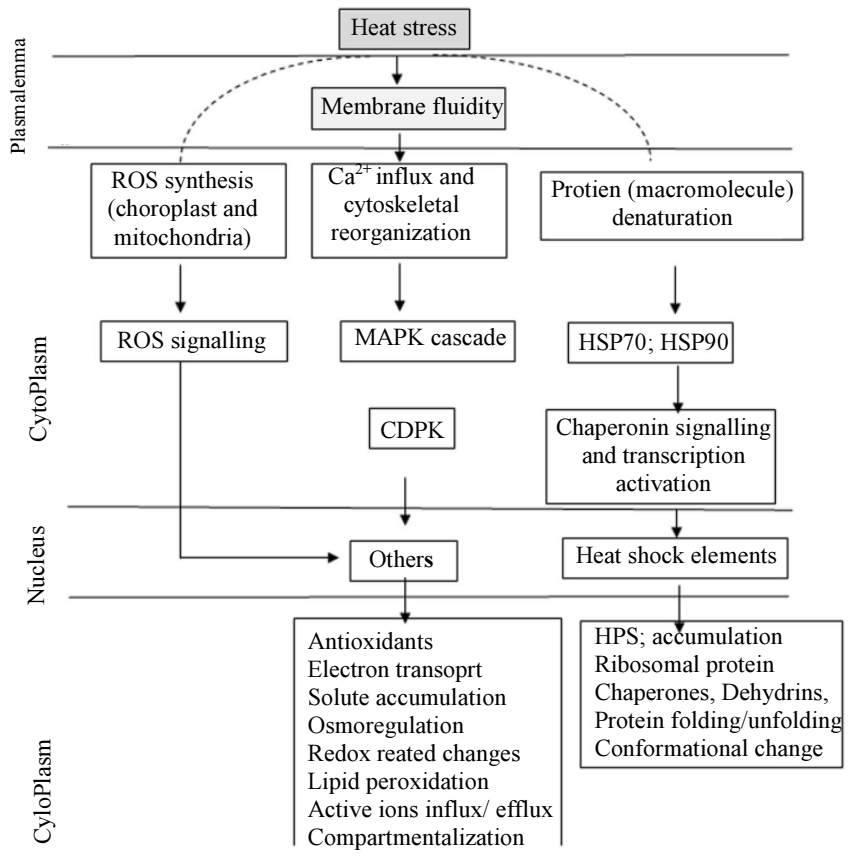

(A) 


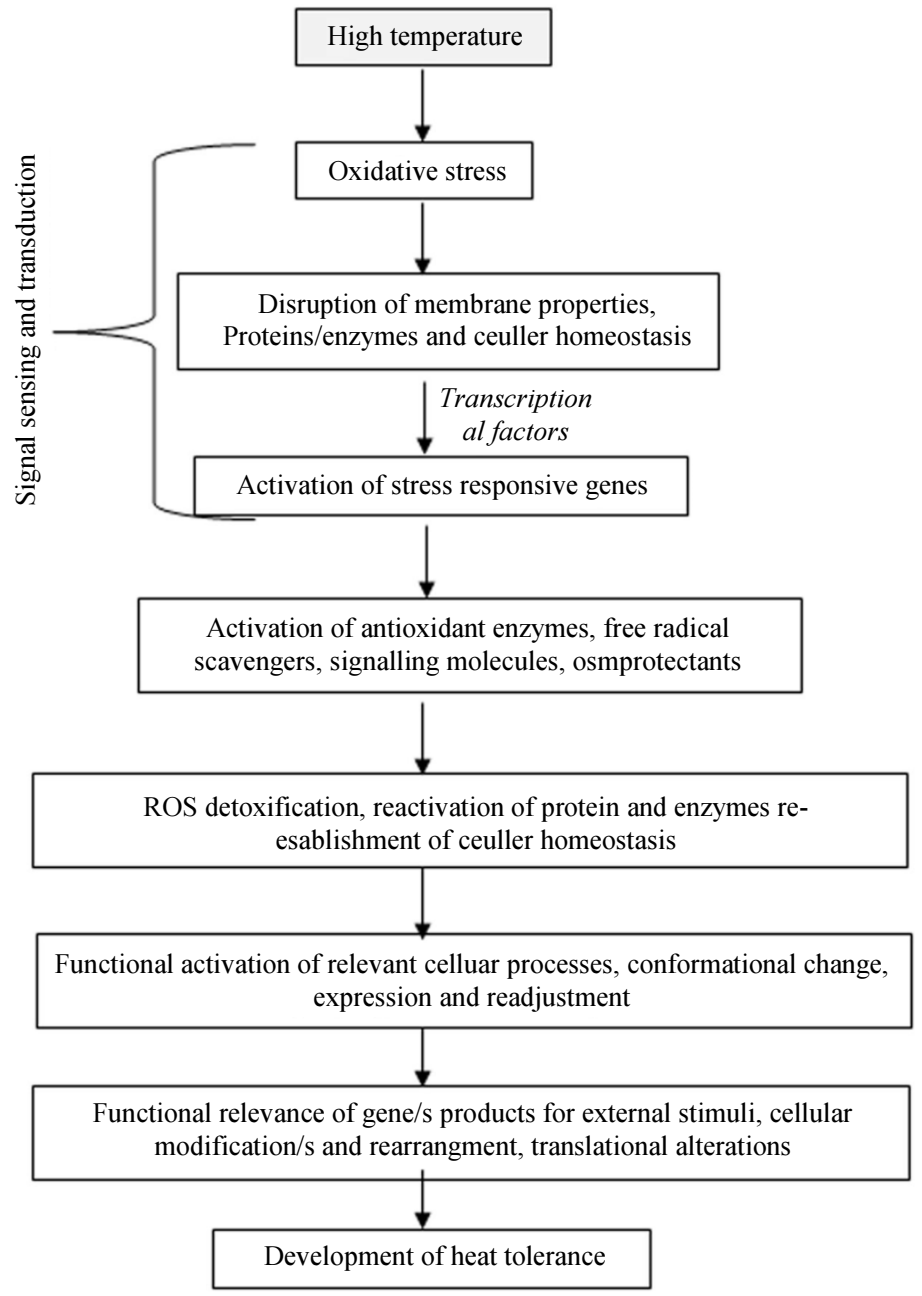

(B)

Fig. 3: (A) Illustration of heat-stress tolerance mechanisms in plants. MAPK, Mitogen activated protein kinases; ROS, reactive oxygen species; HAMK, heat shock activate kinases; HSE, heat shock element; HSPs, heat shock proteins; CAPK, calcium dependent protein kinase; HSK, histidine kinase (Partly adapted form Wahid et al., 2007). (B) Schematic representation of heat induced signal transduct ion and development of heat tolerance in plants (Partly adapted from Hasanuzzaman et al., 2013a)

This article was operated only in relation to vegetative features. It is proposed that the trace of sodium chloride therapy on output and output. Also, the article was carried out with sodium chloride saline therapy and thus the next offer of trialing of other salinity therapys on herbal and functional features. The herbing bed was an amalgamation of cocopeat and sand. It is better to test on local herbages of area in other sub stratums.

Figure 3 displays Design of heat-stress acceptance instruments in herbs. MAPK, Mitogen triggered protein kinases; ROS, sensitive oxygen types; HAMK, heat shock trigger kinases; HSE, heat shock component; HSPs, heat shock proteins; CAPK, calcium reliant on protein kinase; HSK, histidine kinase (Partly adapted form Wahid et al.,
2007). It also shows Diagram depiction of heat persuaded indication transduct ion and expansion of heat acceptance in herbs (Partly adapted from Hasanuzzaman et al., 2013a).

\section{Acknowledgment}

This research was supported by the Isfahan University of the Technology. We thank our all authors who provided insight and expertise that greatly assisted the research.

\section{Author's Contributions}

All authors contributed to design the study, write and revise the manuscript. 


\section{Ethics}

The present Study and ethical aspect were approved by the Isfahan University of the Technology. The present study was approved by the Isfahan University of Technology.

\section{References}

Grieve, C.M., J.A. Poss, S.R. Grattan, D.L. Suarez and S.E. Benes et al. 2004. Evaluation of salt-tolerant forages for sequential water reuse systems: II. plantion relations. Agri. Water Manag., 2: 121-135.

DOI: 10.1016/j.agwat.2004.04.012

Chris, C.T., 1996. Plants for constructed wetland treatment systems -a comparison of the growth and nutrient uptake of eight emergent species. Ecological Eng., 7: 59-83.

David, G.M., S.E. Benes and H.C. Norman, 2007. Biosaline agriculture for forage and livestock production. Agri. Ecosystems Environ., 119: 234-248.

Durrant, M.J., S.J. Mash and K.W. Jaggard, 1993. Effects of seed advancement and sowing date on establishment, bolting and yield of sugar beet. J. Agric. Sci. Combridge, 121: 333-341.

Elisa, D.C., A. Boullemant and R. Courtney, 2019. A field assessment of bauxite residue rehabilitation strategies. Sci. Total Environ., 663: 915-926.

Farooq, M., S.M. Basra and A.N. Ahmad, 2007. Imporoving the performance of transplanted rice by seed priming. plant growth regul., 51: 129-137.

Foti, R., K. Abureni, A. Tigere, J. Gotosa and J. Gere, 2008. The efficacy of different seed priming osmotic on the establishment of maize (Zeal mays L.) caryopses. J. Arid Environ., 72: 1127-1130.

DOI: $10.1016 /$ j.jaridenv.2007.11.008

Foti, S., S.L. Cosentino, C. Patane and G.M. D'Agosta, 2002. Effect of osmoconditioning upon seed germination of sorghum (Sorghum bicolor (L.) Moench) under low temperatures. Seed Sci. Technol., 30: 521-533.

Francisco, J. S. Daz and R. Grattan, 2009. Performance of tall wheatgrass (Thinopyrum ponticum, cv. 'Jose') irrigated with saline-high boron drainage water: Implications on ruminant mineral nutrition. Agri. Ecosystems Environ., 131: 128-136.

Fret, J.J., W.G. Pill and D.C. Momeau, 1991. A comparison of priming agents for tomato and asparagus seeds. HortSicence, 26: 1158-1159.

Ghavami, F. and A. Rezai, 2000. Study of relationship among morphological and phonological.

Grattan, S.R., C.M. Grieve, J.A. Poss, P.H. Robinson and D.L. Suarez et al, 2004. Evaluation of salttolerant forages for sequential water reuse systems: I. Biomass production. Agri. Water Manag., 70: 109-120. DOI: 10.1016/j.agwat.2004.04.010
Greenwood, E.A.N. and J.D. Beresford, 1980. Evaporation from vegetation in landscapes developing secondary salinity using the ventilatedchamber technique: II. Evaporation from Atriplex plantations over a shallow saline water table. J. Hydrol., 45: 313-319.

Gulzar, S. and M.A. Khan, 2001. Seed germination of a halophytic grass Aeluropuslangopoides. Annals botany, 87: 319-324.

Guzman, M. and J. Olave, 2004. Effects of n-form and saline priming on germination and vegetative growth of galia-type melon (Cucumis Melo L. cv. Primal) under salinity. Acta Hort. ISHS, 659: 253-260.

Haigh, A.M., F.W.R. Barlow and F.I. Miltorpe, 1985. Field emergence of tomato, carrot and onion seeds primed in an aerated salt solution. J. Am. Soc. Horticulture Sci., 111: 660-665.

Hardegree, S.P. and V.S.S. Vactor, 2000. Germination and emergence of primed grass seeds under field and simulated-field temperature regimes. Ann. Bot. 85: 379-390.

Harris, D., 1996. The effect of manure, genotype, seed priming, depth and data of sowing on the emergence and early growth of sorghom bicolor L. Moench in semi-arid Botswana. Soil Tillage Res., 40: 73-88.

Harris, D., A.K. Pathan, P. Gothkar, A. Joshi and P. Nyamudeze et al., 2001. On-farm seed priming: Using participatoty methods to revive and refine a key technology. Agri. Syst., 69: 151-164.

Hayley, C., D. Norman, G. Masters and E.G. BarrettLennard, 2013. Halophytes as forages in saline landscapes: Interactions between plant genotype and environment change their feeding value to ruminants. Environ. Experimental Botany, 92: 96-109.

Heidari-Sharifabad, H. and H. Mirzaie-Nodoushan, 2006. Salinity-induced growth and some metabolic changes in three Salsola species. J. Arid Environ., 4: 715-720.

Herbage, D., J.M. Lucas and A. Huc, 1974. Collagen and proteoglycan interactions in bovine articular cartilage. Biochim. Biophy. Acta Protein Struct., 336: 108-116.

Heydecker, W., 1977. Stress and Seed Germination: An Agronomic View. In: The Physiology and Biochemistry of Seed Dormancy and Germination. Khan, A. (Ed.), North Holland Publishing Co. Amsterdam. pp: 273-276.

Horie T., I. Karahara and M. Katsuhara, 2012. Salinity tolerance mechanisms in glycophytes: An overview with the central focus on rice plants. Springer Open. 5: 11. DOI: 10.1186/1939-8433-5-11. 
Hus, J.L. and J.M. Sung, 1997. Antioxidant role of glutatnione associated with accelerated agina and hydration of triploid watermelon seeds. Physiol. Plantarum, 100: 967-974.

Hussian, M., M.S. Farooq, M.A. Basra and N. Ahmad, 2006. Influence of seed priming techniques on the seedling establishment, yield and quality of hybrid sunflower. Int. J. Agri. Biol., 8: 14-18.

Jennette, S., D. Debouck and J.P. Lynch, 2002. Salinity tolerance in Phesolus vulgaris species during early vegetative growth. Crop Sci., 42: 2184-2192.

Juchem, S.O.,S.E. Benes, P.H. Robinson, S.R. Grattan and M. Brito et al., 2012. Grazing as an alternative for utilization of saline-sodic soils in the San Joaquin Valley: Selenium accretion and performance of beef heifers. Sci. Total Environ., 419: 44-53. DOI: 10.1016/j.scitotenv.2011.06.016

Jumsoon, K., C. Jeuonlai and J. Ywonok, 1996. Effect of seed priming on the germinability of tomato (Lycopersicon esculentum Mill.) seeds under water and saline stress. J. Korean Soc. Horticultural Sci., 37: 516-521.

Kamkar, B., M. Kafi and M.N. Mahallati, 2004. Determination of the most sensitive developmental period of wheat (Triticum aestivum) to salt stress to optimize saline water utilization. Proceedings of the 4th International Crop Science Congress, (CSC' 04), pp: 1-6.

Kara, I.G.N., 1998. Response of wheat and barely during germination to seed osmopriming at different water potential. J. Agronomy Crop Sci., 181: 229-235.
Kaur, S., A.K Gupta and N. Kaur, 2002. Effect of osmo and hydro priming of chickpea seeds on theperformance of crop in the field. Chickpea Pigeon Pea News Lett., 9, 15-17.

Khorasani, G.R. and D.G. Armstrong, 1990. Effect of sodium and potassium level on the absorption of magnesium and other macrominerals in sheep. Live Stock Product. Sci., 24: 223-235.

Michael, C.S., 1997. Adaptation of plants to salinity. Adva. Agronomy, 60: 75-120.

Michell, A.R., 1995. Body Sodium in Context: Distribution, Functions and Regulation. 1st Edn., The Clinical Biology of Sodium, Pergamon, ISBN-10: 9781483100821 , pp: 388.

Robinson, P.H., S.R. Grattan, G. Getachew, C.M. Grieve and J.A. Poss et al., 2004. Biomass accumulation and potential nutritive value of some forages irrigated with saline-sodic drainage water. Anim. Feed Sci. Technol., 111: 175-189. DOI: 10.1016/S0377-8401(03)00213-X

Suyama, H., S.E. Benes, P.H. Robinson and S. Grattan, 2007. Forage yield and quality under irrigation with saline-sodic drainage water: Greenhouse evaluation. Agri. Water Manag., 3: 159-172. 